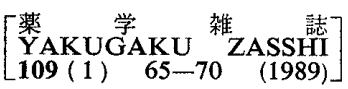

\title{
スルファジメトキシンの腸管吸収に及ぼす血清蛋白結合の置換効果
}

\author{
今村順茂, $*$ 揚村浩文, 小田切優樹 \\ 熊本大学薬学部
}

\section{Displacing Effect of Serum Protein Binding on Intestinal Absorption of Sulfadimethoxine}

\author{
Yorishige Imamura,* Hirofumi Agemura, \\ and MASAKI OTAGIRI
}

Faculty of Pharmaceutical Sciences, Kumamoto University, 5-I, Oe-honmachi, Kumamoto 862, Japan

(Received July 18, 1988)

The displacing effect of serum protein binding on the intestinal absorption of sulfadimethoxine (SDM) in rabbits was examined by using $N^{4}$-acetylsulfadimethoxine ( $N^{4}$-AcSDM), a major metabolite of SDM, as a displacing drug. $N^{4}$-AcSDM markedly decreased the in vitro serum protein binding of SDM, while many drugs including phenylbutazone and salicylic acid did not display such a marked decreasing-effect. The intravenous administration of $N^{4}$-AcSDM clearly decreased the in situ intestinal absorption of SDM. As expected, the intravenously administered $N^{4}$-AcSDM enhanced the serum concentration of unbound SDM in the common jejunal vein. However, the intravenously administered $N^{4}$-AcSDM caused no change in the transfer of SDM across the intestinal membrane. These results indicate that the displacement of serum protein binding can become one of factors decreasing the intestinal absorption of SDM.

Keywords — -sulfadimethoxine; intestinal absorption; rabbit jejunum; in situ recirculation technique; $N^{4}$-acetylsulfadimethoxine; serum protein binding; displacing effect

薬物の血清蛋白結合は薬物の組織分布や腎排泄を変化させ，ひいては薬効・毒性に影響を及ぼすことが多くの 研究報告で明らかにされている.1) しかしながら，薬物の腸管吸収に血清蛋白結合がどのように関与しているか まだほとんど分かっていない，従来から消化管膜を透過した薬物分子は，血清蛋白質と結合し，また血流を介し てただちに運びさられるため，その部位での非結合形薬物濃度は低く，消化管膜の両側で絶えず大きな濃度勾配 が維持されていると考兄られている。ところが，薬物と血清蛋白質との結合が他の薬物住っって強く置換される 場合や，血清蛋白質の急激な減少が認められる場合には，漿膜側の非結合形薬物濃度が著しく上昇し粘膜側と漿 膜側の濃度勾配が小さくなるため, 薬物の腸管吸収が減少する可能性が考兄られる.

最近著者らは，持続性サルファ剤であるスルファジメトキシン (SDM) の血清蛋白結合が，その主代謝物であ る $N^{4}$-アセチルスルファジメトキシン $\left(N^{4}-\mathrm{AcSDM}\right)$ 《よって強く置換されることをウサギを用いて明らかにし てきた. ${ }^{2)}$ そで本研究では，この SDM と $N^{4}$-AcSDM との間で垫められる強い蛋白結合置換現象着目し, SDM の腸管吸収に及ぼす血清蛋白結合の置換効果について詳細な検討を試みた。

\section{実験 の 部}

実験材料 1) 薬物一一本研究で用いた薬物は以下に示す各社より恵与されたもの, 又は市欺のものを使用 した. SDM (第一製薬), フェニルブタゾン (日本チバガイギー), フロセミド (興和), サリチル酸 (小野薬品), クロルプロパミド (小野薬品), イブプロフェン(日清製薬), プロベネシド(科研製薬), メフェナム酸 (吉富製薬), ケトプロフェン(科研製薬), インドメタシン (日本シイベルヘグナー), ブコローム (武田薬品). $N^{4}$-AcSDM は宇 野らの方法3) に準じて SDM から合成し, 融点, 元素分析及び赤外吸収 (IR) スペクトルにより確認したものを 用いた。 その他の試薬類は市販の特級品を使用した。 
2）実験動物一一雄性日本種白色ウサギ（体重 $2.5-3.0 \mathrm{~kg}$ )を 36-42 時間絶食した後に使用した. ただし絶 食期間中でも水は自由に与えた。

蛋白結合実験＼cjkstart蛋白結合実験は限外沪過法4)て従って行った。

1）In Vitroでの血清㔻白結合の測定一一試料血清の調製：あらかじめウサギより得られた血清の9 容に，最 終薬物濃度が所定濃度になるように薬物溶液の 1 容を添加したものを試料血清とした。奏験操作：ビスキング チューブ (サイズ, 8/32) の一端を縫合糸で結び袋状とし, 他端を輪ゴムで限外沪過装置に固定し, 室温で約 90 分間乾燥させた。 限外汇過装置のチューブ内に試料血清 $1.2 \mathrm{ml}$ をれ， $3000 \mathrm{rpm}$ で 40 分間遠心分離した. 得

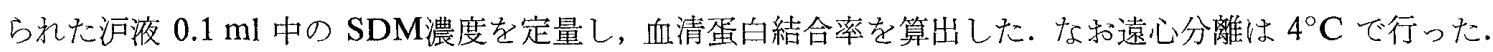

2）総空腸静脈での血清蛋白結合の測定——In situ 腸管吸収垁験に括ける所定の時間に総空腸静脈から約 6 $\mathrm{ml}$ の血液を採取した，その血液を室温で 1 時間放置後, $3000 \mathrm{rpm}$ で 15 分間遠心分離し試料血清を得た。奏験 操作：In vitro での血清蛋白結合の測定の場合と同様て行った。血清及び污液中の SDM 濃度を定量し; 血清蛋 白結合率を算出した。

In Situ 腸管吸収実験Ｇoto らの in situ 腸管還流法 ${ }^{5)}$ 一部改変した方法で行った.

1）還流液及び $N^{4}-\mathrm{AcSDM}$ 注射液の調製——還流液は $\mathrm{SDM}(500 \mu \mathrm{g} / \mathrm{ml})$ 及びフェノールレッド（内容指示 薬， $10 \mu \mathrm{g} / \mathrm{ml}$ ) を $1 / 15 \mathrm{M}$ 等張りン酸緩衝液（pH 7.4）に溶解して調製した。亦た $N^{4}-\mathrm{AcSDM}$ 注射液は， $N^{4}$ $\mathrm{AcSDM}$ を等モルの水酸ナトリウムとともに生理食塩液に溶解して調製した。

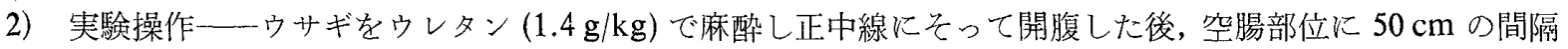
でカニェーレを挿入し縫合系で結紮固定した，腸内容を生理食塩液で十分に洗浄除去した後，カニューレを還流 ポンプに接続し還流を開始した。な怙還流液の液量は $150 \mathrm{ml}$ とし $30 \mathrm{ml} / \mathrm{min}$ の速度で還流させた。経時的に 1.0 $\mathrm{ml}$ の還流液を採取し，SDMとフェノールレッドの定量を実施した。

3） $N^{4}$-AcSDM の静脈内投与一一 $N^{4}$-AcSDM は in situ 晹管吸収実験開始 1 時間目に $50 \mathrm{mg} / \mathrm{kg}$ の投与量で 耳介静脈内に投与した。な括ウサギに $N^{4}-\mathrm{AcSDM}$ を静脈内投与した場合に括いて，血清中に SDM は検出され ず，ウサギの体内では脱アセチル化反応は起こっていないことが確認された。

4）空腸動脈及び空腸静脈かららの血液の採取——In situ 腸管吸収実験に沶いて， $N^{4}$-AcSDM 静脈内投与 10 分 前と 10 分後に, 吸収部位の空腸動脈と空腸静脈からそれぞれ $0.5 \mathrm{ml}$ ずつ血液を採取した。血液は直らに $0.01 \%$ サポニン溶液 $2.0 \mathrm{ml}$ を加え十分に溶血させた後, 血液中 (全血中) のSDM 濃度の定量を実施した。

In Situ 腸管分泌実験最近著者らによって報告された方法 ${ }^{6)}$ に従って行った。開腹手術は in situ晹管吸収 実験の場合と全く同様に行った。等張リン酸緩衝液 $(1 / 15 \mathrm{M}, \mathrm{pH} 7.4)$ が $6 \mathrm{ml} / \mathrm{min}$ の速度で上部カニューレから 腸管腔へ流入し，下部カニューレから流出してくるよらに還流ポンプを接続した. SDM (投与量 $50 \mathrm{mg} / \mathrm{kg}$ )を静 脈内投与した後, 流出してくる等張リン酸緩衝液 $(1 / 15 \mathrm{M}, \mathrm{pH} 7.4)$ を 5 分ごとに採取し，との容量と SDM 濃度 の測定を行った.

摘出反転腸管実験 McElnay らの方法で一部改変した方法8)で行った。

1) 薬物溶液の調製一一薬物溶液は SDM $(500 \mu \mathrm{g} / \mathrm{ml})$ 又は $N^{4}-\mathrm{AcSDM}(500 \mu \mathrm{g} / \mathrm{ml})$ をタイロード液 (栄養液) に溶解することにより調製した。

2）寒験操作——サギの腸管（空腸）を摘出し，生理食塩液中で注意深く反転させ，実験装置に結紫固定し た. 反転させた腸管の内側に $N^{4}-\mathrm{AcSDM}$ 溶液 $7.0 \mathrm{ml}$ を入れた後, $37^{\circ} \mathrm{C}$ に保った $\mathrm{SDM}$ 溶液 $(70 \mathrm{ml})$ 中に浸し 酸素を送り込んだ.実験開始後, 内液を経時的に $0.1 \mathrm{ml}$ ずつ採取し, SDM の定量を行った.

定量法 SDM の定量は Bratton-Marshall 法 ${ }^{9)}$ に従って行った. $N^{4}-\mathrm{AcSDM}$ の濃度は, 総 (未変化体 $+N^{4}-$ アセチル体) SDM 濃度から SDM 濃度をさし引いて求めた。な総 SDM 濃度は, 沸騰水浴中で 1 侍間加水分 解後 Bratton-Marshall 法 ${ }^{9}$ により定量した。還流液中のフェノールレッドの定量は，1N 水酸化ナトリウム溶 液を加光て発色させ，波長 $555 \mathrm{~nm}$ で吸光度を測定する方法で行った.

統計処理＼cjkstart得られた実験值は平均値土標準誤差で表示し, 有意差の検定は Student の $t$ 検定を適用した。

$$
\text { 結果 }
$$

\section{In Vitro での SDM の血清蛋白結合に及ぼす $N^{4}-\mathrm{AcSDM}$ と各種薬物の影響}

SDM とウサギ血清との in vitro での蛋白結合が， $N^{4}$-AcSDM 又は各種薬物を添加するとどのように変化する か検討した。 その結果が Table I にまとめて示されている。これらの結果から明らかなるらに， $N^{4}$-AcSDM は SDM の血清蛋白結合を著しく減少させたが，各種薬物の中でこのよらな著しい減少効果を示すものは見当らな かった。 
2. SDM の in Situ 腸管吸収に及ぼす $N^{4}$ AcSDM の影響

In situ 腸管還流法により, SDM の腸管吸収に及 ぼす $N^{4}$-AcSDM の影響を調べた。Fig. 1 は還流液 中の SDM の残存率の対数を時間に対してプロット した代表的な例を示したものである。還流液中の SDM の残存率は，実験開始 1 時間目に $N^{4}-\mathrm{AcSDM}$ を静脈内投与すると，生理食塩液を静脈内投与した 結果から予想される值よりも明らが增加した。こ のことは，SDM の腸管吸収が $N^{4}$-AcSDM を静脈 内投与すると減少することを示している，しかしこ の効果は 30 分程度しか持続せず，一時的なもので あった。

\section{SDM の腸管からの吸収速度に及ぼす $N^{4}-$} AcSDM の影響

Fig. 2 は in situ 腸管還流法による SDM の腸管吸 収を模式的に示したものである。いま $N^{4}$-AcSDM を静脈内投与前の $\mathrm{SDM}$ の吸収速度を $R_{\mathrm{a}}$, 空腸動脈

と空腸静脈に批ける SDM の血液中 (全血中) 濃度をそれぞれ $C_{A}, C_{\mathrm{V}}$, 及び血流速度を $F$ とすると, 次式が成 り立つ。

$$
R_{\mathrm{a}}=F\left(C_{\mathrm{v}}-C_{\mathrm{A}}\right)
$$

同梯に， $N^{4}-\mathrm{ACSDM}$ を静脈内投与後の SDM の吸収速度を $R_{\mathrm{a}}{ }^{\prime}$, 空腸動脈々空腸静脈における SDM の血液中 (全血中) 濃度をと就ぞれ $C_{\mathrm{A}}{ }^{\prime}, C_{\mathrm{v}^{\prime}}$ ，及び血流速度を $F^{\prime}$ とすると次式が成り立つ.

$$
R_{\mathrm{a}}{ }^{\prime}=F^{\prime}\left(C_{\mathrm{v}}{ }^{\prime}-C_{\mathrm{A}}{ }^{\prime}\right)
$$

ここで $N^{4}$-AcSDM の静脈内投与が血流速度に影響を及洼さないと仮定すると, 式 (1) と式 (2) より次式が得ら れる。

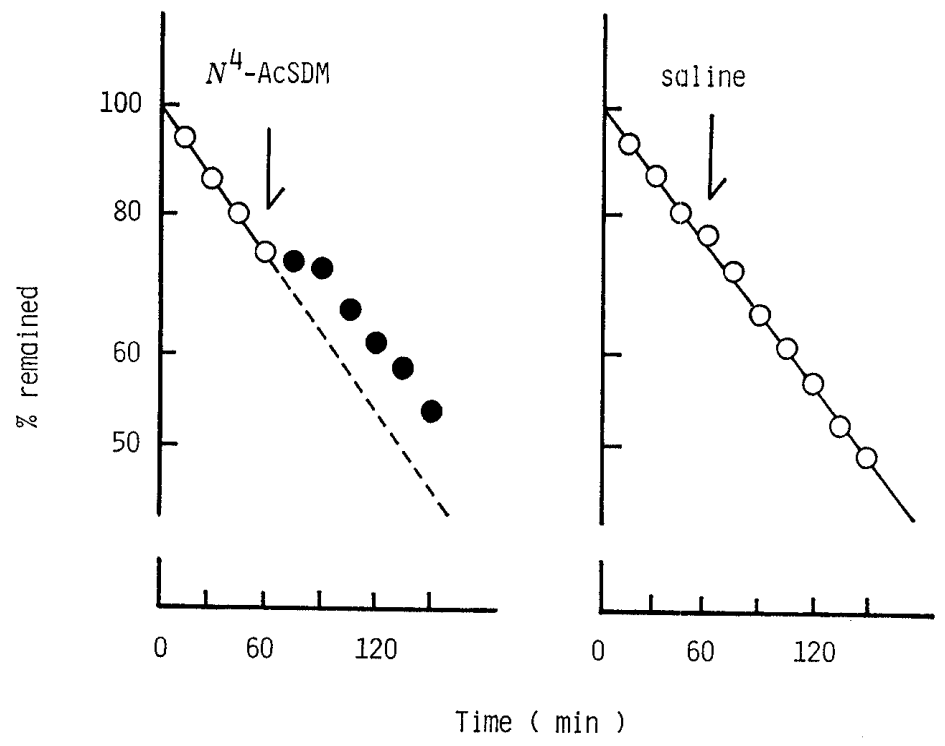

Fig. 1. Effect of Intravenously Administered $N^{4}-\mathrm{AcSDM}$ on the in Situ Intestinal Absorption of SDM

Dose of $N^{4}$-AcSDM, $50 \mathrm{mg} / \mathrm{kg}$. This figure shows typical data.
TABLE I. Effect of $N^{4}$-AcSDM and Various to Rabbit Serum

\begin{tabular}{lc}
\hline \hline $\begin{array}{c}\text { SDM, } N^{4} \text {-AcSDM or various } \\
\text { drugs }\end{array}$ & $\%$ bound \\
\hline SDM alone & 98.5 \\
SDM $+N^{4}$-AcSDM & 70.4 \\
SDM + phenylbutazone & 96.1 \\
SDM + salicylic acid & 95.1 \\
SDM + furosemide & 95.8 \\
SDM + chlorpropamide & 93.1 \\
SDM + ibuprofen & 98.4 \\
SDM + probenecid & 98.4 \\
SDM + mefenamic acid & 96.6 \\
SDM + ketoprofen & 94.0 \\
SDM + indomethacin & 97.7 \\
SDM + bucolome & 94.2 \\
\hline
\end{tabular}

Concentration of SDM, $100 \mu \mathrm{g} / \mathrm{ml}$. Concentration of $N^{4}$ AcSDM or various drugs, $100 \mu \mathrm{g} / \mathrm{ml}$. 


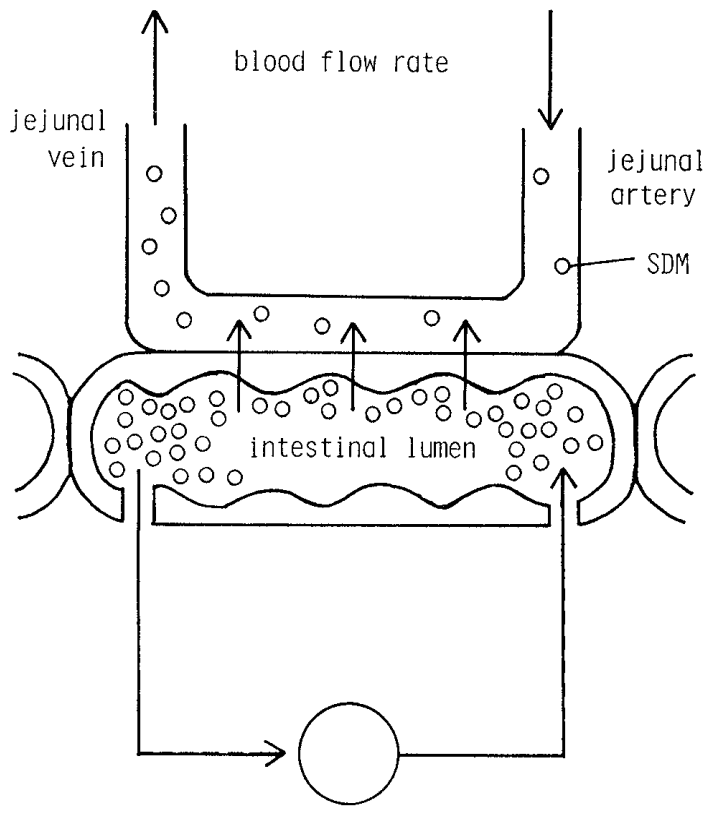

perfusion pump

Fig. 2. Schematic Diagram of the in Situ Intestinal Absorption of SDM
TABLE II. Effect of Intravenously Administered $N^{4}$-AcSDM on Absorption Rate of SDM

\begin{tabular}{lcc}
\hline \hline & $N^{4}-\mathrm{AcSDM}$ & Saline \\
\hline$C_{\mathrm{V}}-C_{\mathrm{A}}(\mu \mathrm{g} / \mathrm{ml})$ & $24.2 \pm 4.1$ & $20.2 \pm 3.5$ \\
$C_{\mathrm{V}}{ }^{\prime}-C_{\mathrm{A}}{ }^{\prime}(\mu \mathrm{g} / \mathrm{ml})$ & $15.2 \pm 2.1$ & $23.3 \pm 5.3$ \\
$R_{\mathrm{a}}{ }^{\prime} / R_{\mathrm{a}}$ & $\left.0.66 \pm 0.07^{a}\right)$ & $1.14 \pm 0.14$ \\
\hline
\end{tabular}

Each value represents the mean \pm S.E. of 5 rabbits. a) Significantly different from saline, $p<0.05$. Dose of $N^{4}$-AcSDM, $50 \mathrm{mg} / \mathrm{kg}$.

$$
\frac{R_{\mathrm{a}}{ }^{\prime}}{R_{\mathrm{a}}}=\frac{C_{\mathrm{v}^{\prime}}-C_{\mathrm{A}}{ }^{\prime}}{C_{\mathrm{V}}-C_{\mathrm{A}}}
$$

この式は，空腸動脈と空腸静脈の血液中 (全血中) の SDM 濃度が分かれば， $N^{4}$-AcSDM を静脈内投 与前に対する投与後のSDM の吸収速度の比が求ま ることを意味している。 そこで式 (3) に従って， $N^{4}$ $\mathrm{AcSDM}$ を静脈内投与前に対する投与後の SDM の 吸取速度の比を求めた。な就㛊実験として，生理 食塩液を静脈内投与前に対する投与後のSDM の吸 収速度の比について子調べた。その結果 Table II に 示すよらに，生理食塩液を静脈内投与したときの

$\mathrm{SDM}$ の吸收速度の比は $1.14 \pm 0.14$ となったのに対し， $N^{4}-\mathrm{AcSDM}$ を静脈内投与したとさの SDM の吸収速度

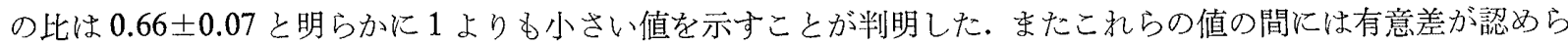
れた。これらの結果は, SDM の吸収速度が $N^{4}-\mathrm{AcSDM}$ の静脈内投与により減少することを示唆している.

\section{SDM $の$ in Situ 腸管分泌に及ぼす $N^{4}$-AcSDM の影響}

静脈内投与された薬物はその一部が腸管の脈管系から腸管腔へ分泌されることが知られている.10)薬物の腸管 腔への分泌には，血清中の非結合形薬物濃度が関与するが，それ以外飞も血流速度，膜透過性及び腸管粘膜での 代謝などの因子が関与しているものと考光られる。ところで前述したよらに，SDM の腸管吸収は $N^{4}-\mathrm{AcSDM}$ を静脈内投与すると減少するが，も乙との原因が血清中の非結合形 SDM 濃度の上昇に基づくものであるなら ば, SDM の腸管腔への分泌は $N^{4}-\mathrm{AcSDM}$ を静脈内投与すると増加するものと予想される，一方，その原因が 血流速度や膜透過性の減少，もしくは腸管粘膜に拉けるアセチル化 ${ }^{11}$ の増大に基づくものであるならば，SDM の腸管腔への分泌は $N^{4}-\mathrm{AcSDM}$ を静脈内投与するといずれも減少するものと予想される。そこで SDMの腸管 腔への分泌に及ぼす $N^{4}$-AcSDM 静脈内投与の影響を in situ 腸管分泌奉験法により検討した. その結果 Fig. 3 に示すように, SDM の晹管腔への分泌は $N^{4}$-AcSDM を静脈内投与すると明らかに増加した。したがって， $\mathrm{SDM}$ の腸管吸収が $N^{4}-\mathrm{AcSDM}$ の静脈内投与により減少する原因は，非結合形 SDM 濃度の上昇によるもので あることが強く示唆された。

\section{SDM の腸管膜透過性に及ぼす $N^{4}-\mathrm{AcSDM} の$ 影響}

SDM の腸管膜透過性に及ぼす $N^{4}$-AcSDM の影響を摘出反転腸管実験法により検討した。その結果 Fig. 4 か ら明らかなように，腸管の粘膜側から漿膜側への SDM の透過量は， $N^{4}-A c S D M$ 存在下に扣いてほとんど変 化しなかった。したがって，N4-AcSDM はSDM の腸管膜透過性に影響を及ぼさないことが確められた。

\section{6. 総空腸静脈における SDM の血清蛋白結合に及ぼす $N^{4}$-AcSDM の影響}

SDM の腸管吸収に及ぼす血清蛋白結合の置換効果を明らかにするためには，腸管吸収に直接に関与する吸収 部位の血管内での血清蛋白結合を調べることが重要と思われる。しかし，in situ腸管還流法にふ晾る吸収部位の 血管でめる空腸静脈からは，極めて少量の血液しか採取できず，血清蛋白結合実験を実施できなかった。そこで 空腸静脈よりも太い血管である総空腸静脈から血液の採取を行い，SDM の血清蛋白結合に及ぼす $N^{4}$-AcSDM の影響を調べた。なお $N^{4}-\mathrm{AcSDM}$ を静脈内投与したとき，SDM の腸管吸収の減少が約 30 分間続いているの 




Fig. 3. Effect of Intravenously Administered $N^{4}$-AcSDM on the in Situ Intestinal Secretion of SDM

Dose of $N^{4}-A c S D M, 50 \mathrm{mg} / \mathrm{kg}$. This figure shows typical data.

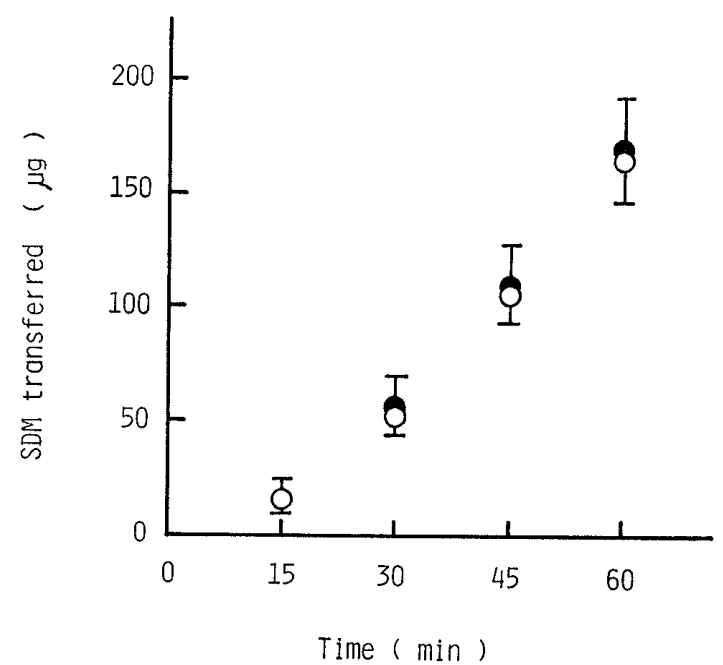

Fig. 4. Effect of $N^{4}$-AcSDM on Transfer of SDM across the Intestinal Membrane

Each point represents the mean \pm S.E. of 5 rabbits. $\mathrm{O}$, SDM alone; $\boldsymbol{O}$, with $N^{4}$-AcSDM.
TABle III. Serum Protein Binding of SDM in Common Jejunal Vein at $10 \mathrm{~min}$ before and after Intravenous Administration of $N^{4}-\mathrm{AcSDM}$

\begin{tabular}{lrc}
\hline \hline & \multicolumn{1}{c}{ Before } & After \\
\hline $\begin{array}{l}\text { Total }{ }^{a)} \text { SDM concn. } \\
(\mu \mathrm{g} / \mathrm{ml})\end{array}$ & $113.8 \pm 12.5$ & $52.7 \pm 3.2^{b)}$ \\
Unbound SDM concn. & & \\
$(\mu \mathrm{g} / \mathrm{ml})$ & $2.1 \pm 0.6$ & $32.5 \pm 2.5^{c)}$ \\
$\%$ bound & $98.3 \pm 0.4$ & $38.5 \pm 2.0^{c)}$ \\
\hline
\end{tabular}

Each value represents the mean \pm S.E. of 5 rabbits. a) bound + unbound. b) Significantly different from "Before", $\quad p<0.005$. c) Singificantly different from "Before", $p<0.001$.

で, 非結合形 SDM 濃度の経時変化を調べることが 必要と思われる。しかし今回は，血液の経時的な採 取が困難である理由から， $N^{4}$-AcSDM を静脈内投 与 10 分後に拈ける非結合形 SDM 濃度の及を調べ

た。その結果を Table III に示すが, SDM の血清蛋白結合は $N^{4}$-AcSDM を静脈内投与すると著しく減少す ることが明らかである。また非結合形 SDM 濃度は， $N^{4}-\mathrm{AcSDM}$ を静脈内投与すると， $2.1 \pm 0.6 \mu \mathrm{g} / \mathrm{ml}$ から $32.5 \pm 2.5 \mu \mathrm{g} / \mathrm{ml}$ へと約 15 倍も上昇することが判明した.

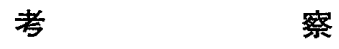

$\mathrm{SDM}$ の腸管吸収は $N^{4}$-AcSDM を静脈内投与すると減少することが in situ 腸管吸収実験の結果から明らかに

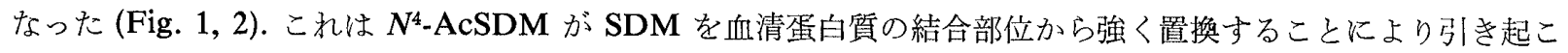
されるものと考えられる。事実, 総空腸静脈に括ける非結合形 SDM 濃度は, $N^{4}$-AcSDM を静脈内投与すると 約 15 倍も上昇することが確められた (Table III).なお SDM の腸管吸収に関与している筀腸静脈での非結合形 $\mathrm{SDM}$ 濃度は, 総空腸静脈のように他の空腸静脈からの血液の流入がないため, $N^{4}-A c S D M$ の静脈内投与によ 
り，更に顕著な上昇が認められるものと思われる。

ところで $N^{4}-\mathrm{AcSDM}$ は SDM の代謝物であるため, ${ }^{12)}$ 代謝によって生成された $N^{4}-\mathrm{AcSDM}$ が SDM の血清 蛋白結合に影響を及ぼす可能性がある。しかし，in situ 腸管吸収実験において $N^{4}$-AcSDM を静脈内投与前の総 空腸静脈での血清中の $N^{4}-\mathrm{AcSDM}$ 濃度, すなわち SDM の代謝によって生じた $N^{4}-\mathrm{AcSDM}$ の濃度は $10.2 \pm$ $1.5 \mu \mathrm{g} / \mathrm{ml}(n=5)$ であり，この濃度は $N^{4}-\mathrm{AcSDM}$ を静脈内投与後の $N^{4}-\mathrm{AcSDM}$ 濃度 $(301.5 \pm 8.6 \mu \mathrm{g} / \mathrm{ml}, n=5)$ と比べて著しく低く，SDM の血清蛋白結合にはほとんど影響を及ぼさないものと考兄られた。

$\mathrm{SDM}$ の吸収速度に及ぼす $N^{4}-\mathrm{AcSDM}$ の影響を調べる実験において， $N^{4}$-AcSDM の静脈内投与は血流速度に 影響を及ぼさないものと仮定した，本実験では史際に血流速度を測定していないが， $N^{4}-A c S D M$ 血流速度を 変化させるよらな薬理作用がないこと, 及び $N^{4}-\mathrm{AcSDM}$ の静脈内投与による SDM の腸管吸収の減少が，血流 速度の減少に基づくものでないことが in situ 腸管分泌実験の結果から予想されることからこのように仮定した。 しかしいずれにしても，N4-AcSDM の静脈内投与が血流速度に影響を及ぼさないかどらか詳細な検討を要する。

以上のように SDM の腸管吸収は，血清蛋白結合の置換が起こると減少することが明らかとなった。一般に経 口投与された薬物は，吸収部位の血管内に拈いて体内の他の部位の血管内よりも高濃度に存在し，そのため薬物 と血清蛋白質との結合は飽和状態に達している場合が多いと考えられる。このような場合は，高い血清蛋白結合 性を示す他の薬物を静脈内投与すると，本研究で浔められたよらな薬物の腸管吸收の減少が引き起こされる可能 性がある。しかしながら，その減少效果は一時的なものであり，臨床的な面からはそれほど闍題にならないよう に思われる。

\section{引用文献}

1) a) B. K. Martin, Nature (London), 207, 274 (1965); b) M. C. Meyer, D. E. Guttman, J. Pharm. Sci., 57, 895 (1968); c) J. J. Vallner, ibid., 66, $447(1977) ; d)$ 瀬崎 仁, 堀 了平 监訳, “S. H. Curry: 加 だの中の薬の動き一薬物の生体内挙動と速度論, ”廣川書店, 東京, 1980, pp. 79-92.

2) Y. Imamura, H. Mori, H. Ichibagase, Chem. Pharm. Bull., 31, 274 (1983).

3) 宇野豊三, 上田道広, 薬誌, 80, 1785 (1960).

4) Y. Imamura, M. Sonoda, K. Arimori, H. Ichibagase, Chem. Pharm. Bull., 27, 463 (1979).

5) S. Goto, O. Tsuzuki, S. Iguchi, Chem. Pharm. Bull., 19, 944 (1971).

6) Y. Imamura, H. Ichibagase, Chem. Pharm. Bull., 25, 3400 (1977).

7) J. C. McElnay, P. F. D’Arcy, O. Throne, Int. J. Pharm., 7, 83 (1980).

8) Y. Imamura, K. Arimori, M. Sonoda, H. Ichibagase, Chem. Pharm. Bull., 30, 2169 (1982).

9) A. C. Bratton, E. K. Marshall, J. Biol. Chem., 128, 537 (1939).

10) a) K. Arimori, M. Nakano, J. Pharmacobio-Dyn., 8, 324 (1985); b) J. F. Valentine, D. C. Brater, G. J. Krejs, J. Pharmacol. Exp. Ther., 236, 177 (1986).

11) M. Yasuhara, H. Kobayashi, T. Kimura, S. Muranishi, H. Sezaki, J. Pharmacobio-Dyn., 1, 122 (1978).

12) R. H. Adamson, J. W. Bridges, M. K. Kibby, S. R. Walker, R. T. Williams, Biochem. J., 118, 41 (1970). 